\title{
ANALISIS KEBUTUHAN PENGEMBANGAN MULTIMEDIA BERBASIS KVISOFT DIPADUKAN DENGAN GEOGEBRA PADA MATA KULIAH PROGRAM LINIER
}

\author{
Soffi Widyanesti Priwantoro ${ }^{a}$, Syariful Fahmi ${ }^{b}$, Dwi Astuti \\ ${ }^{\text {a }}$ Program Studi Pendidikan Matematika FKIP UAD \\ Jl. Ringroad Selatan, Tamanan, Banguntapan, Bantul Yogyakarta, \\ soffiwidyanesti@pmat.uad.ac.id \\ ${ }^{\mathrm{b}}$ Program Studi Pendidikan Matematika FKIP UAD \\ Jl. Ringroad Selatan, Tamanan, Banguntapan, Bantul Yogyakarta, \\ syariful.fahmi@pmat.uad.ac.id \\ ${ }^{c}$ Program Studi Pendidikan Matematika FKIP UAD \\ Jl. Ringroad Selatan, Tamanan, Banguntapan, Bantul Yogyakarta, \\ dwiastuti.06@gmail.com
}

\begin{abstract}
ABSTRAK
Ada beberapa cara agar pembelajaran berkualitas yaitu ketersediaan dan pemanfaatan media pembelajaran. Kedudukan media pembelajaran memiliki peranan penting karena dapat mempemudah proses pembelajaran seperti membuat suasana belajar yang tidak menarik menjadi menarik. Media belajar mandiri pada era kemajuan teknologi sangat dibutuhkan dalam proses pembelajaran. Penelitian ini bertujuan untuk mengetahui kebutuhan akan media berbasis teknologi pada mata kuliah Program linier yang bersifat menarik, efektif, mandiri dan efisien. Subyek dari penelitian ini adalah mahasiswa yang mengambil mata kuliah Program Linier Semester lima Prodi Pendidikan Matematika FKIP UAD. Teknik pengumpulan data yang digunakan yaitu angket dan wawancara. Hasil dari penelitian menunjukkan bahwa mutimedia berbasis kvisoft flipbook maker yang dipadukan dengan Geogebra dibutuhkan sebagai media pembelajaran yang menarik, efektif, mandiri dan efisien dalam meningkatkan pemahaman pada mata kuliah Program Linier.
\end{abstract}

Kata Kunci : kvisoft, program linier, multimedia.

\begin{abstract}
There are several ways to increase the quality of learning is the availability and utilization of intructional media. The position of instructional media has an important role because it can facilitate the learning process such as making the atmosphere of learning from bored to interesting. Self learning media in technological progress era is needed in the learning process. The purpose of this study is to determine the need of technology based media in Linear Programming courses which is effective, independent and efficient. The subjects of this study are students who take Linear programming courses in 5th semester of mathematics education study Program of FKIP UAD. Data collection techniques using quetionnaires and interviews. The result shows that multimedia based kvisoft flipbook maker combined geogebra is needed as an effective, independent and efficient learning media to improve the understanding of Linear Programming courses.
\end{abstract}


Keywords : kvisoft, linear programming, multimedia

\section{Pendahuluan}

Penggunaan teknologi dalam berbagai bidang sangat diperlukan apalagi pada era modern saat ini. Bidang pendidikan merupakan salah satu aspek yang penting, karena pendidikan dapat meningkatkan dan mengembangkan kualitas generasi penerus dari suatu bangsa. Agar kualitas pendidikan dapat meningkatkan maka kita perlu meningkatkan kualitas pembelajaran di dalam kelas. Ketersediaan bahan ajar sebagai media merupakan salah satu komponen yang dapat mendukung peningkatan kualitas pembelajaran. Bahan ajar merupakan salah satu sumber belajar yang diperlukan oleh mahasiswa agar mahasiswa dapat memperkaya wawasan dan memperbanyak latihan sehingga materi yang menurut mahasiswa sulit dapat menjadi lebih mudah dipahami. Belajar yang didominasi pengajar akan menyebabkan mahasiswa belajar sedikit sekali (Frangenheim : 2005). Pembelajaran akan berlangsung lebih baik apabila pengajr tidak terlalu mendominasi pada kegiatan pembelajaran. Menyediakan bahan ajar yang menarik pada kegiatan pembelajaran dapat mempengaruhi kualitas pembelajaran. Bahan ajar harus didesain menarik dan mempunyai muatan materi yang mudah dipahami oelh mahasiswa. Bahan ajar juga dilengkapi dengan ilustrasi yang menarik yang akan dapat meningkatkan rasa ingin tahu mahasiswa dalam memahami materi sehingga mahasisswa dapat memanfaatkan bahan ajar sebagi sumber belajar yang efektif, efisien dan mandiri.

Bahan ajar memungkinkan mahasiswa dapat mempelajari suatu materi secara runtut dan mandiri sehingga mahasiswa dapat menguasai materi secara utuh. Bahan ajar adalah segala bentuk bahan yang digunakan guru/instruktur dalam melaksanankn kegiatan pembelajaran dikelas, bahan yang dimaksud dapat berupa baahn tertulis maupun non-tertulis (Majid: 2008). Salah satu macam bahan ajar adalah bahan ajar interaktif yaitu kombinasi dari dua atauy lebih media (audio, teks, gambar, grafik, animasi dan video) yang oleh penggunanya dimanipulasi atau diberi perlakuan untuk mengendalikan suatu perintah dan atau perilaku alami dari presentasi (Prastowo:2013). Bahan ajar interaktif ini juga berfungsi untuk meningkatkan proses pembelajaran menjadi leboih efektif, menarik dan mandiri. Salah satu fungsi bahan ajar bagai pengajar adalah meningkatkan proses pembelajaran menjadi lebih efektif dan interaktif sehingga mahasiswa dapat belajar sesuai dengan kecepatan masing-masing dan 
menyesuaikan waktu dari mahasiswa yang tidak bergantung dari pengajar (Prastowo :2012).

Pemilihan bahan ajar sebagai media interaktif yang tepat diharapkan dapat berpengaruh terhadap proses pembelajaran. Teknologi menggunakan komputer berbeda dengan teknologi lainnya karena dapat menyimpan materi dalam bentuk digital dan bisa dibuka sewaktu-waktu. Media interaktif menggunakan teknologi juga dapat menciptakan kemandirian mahasiswa dalam proses pembelajaran (Fahmi, 2014). Salah satu media pembelajaran yang sering digunakan adalah media pembelajaran dengan menggunakan komputer berbasis software/program. Software pada komputer ini dapat dimanfaatkan sebagai alat bantu pembelajaran yang interaktif dengan konsep multimedia. Salah satu media pembelajaran yang diharapkan dapat menciptakan suasana belajar yang menarik dan kondusif yaitu dengan penggunaan multimedia flipbook. Penggunaan media flash flipbook dapat menambah motivasi belajar mahasiswa dan juga dapat mempengaruhi prestasi atau hasil belajar mahasiswa (Ramdania, 2013). Penggunaan flipbook dapat meningkatkan pemahaman dan meningkatkan pencapaian hasil belajar (Nazeri, 2013).

Media pembelajaran berupa modul dapat ditransformasikan penyajiannya kedalam bentuk elektronik sehingga diberi istilah modul elektronik atau modul virtual. Modul elektronik adalah sebuah bentuk penyajian bahan belajar mandiri yang disusun secara sistematis ke dalam unit pembelajaran terkecil untuk mencapai tujuan pembelajaran tertentu yang disajikan dalam bentuk elektronik yang didalamnya terdapat animasi, audio, navigasi yang membuat pengguna lebih interaktif dengan software. Modul elektronik yang bersifat interaktif ini pada proses pembelajarannya akan melibatkan tampilan audio visual, sound, movie dan yang lainnya serta software tersebut pemakaiannya mudah dipahami sehingga dapat dijadikan media pembelajaran yang baik (Gunawan, 2010). Pembuatan media pembelajaran berbasis multimedia dilakukan dengan menggunakan software yang bersifat open source. Software tersebut adalah kvisoft flipbook maker yang merupakan software yang digunakan untuk membuat tampilan buku/bahan ajar lainnya menjadi sebuah buku elektronik digital berbentuk flipbook.

Kvisoft Flippbook maker merupakan perangkat lunak yang menyerupai buku. Namun Perangkat lunak ini dapat Analisis... (Soffi) 
mengubah tampilan PDF yang biasa yang hanya berupa teks saja namun dapat membuat media menjadi lebih variatif dengan mensisipkan audio, video, gambar ataupun dengan software lain sehingga dengan media ini diharapkan pembelajaran menjadi lebih menarik dan mandiri.

Program Linier adalah salah satu mata kuliah yang harus ditempuh oleh mahasiswa di program studi pendidikan matematika UAD. Pada mata kuliah ini belum ada dosen yang menyediakan media pembelajaran berbasis software tertentu yang mempermudah mahasiswa untuk belajar mandiri. Penggunaan bahan ajar seperti buku, handout, maupun lembar kerja mahasiswa masih membuat mahasiswa kesulitan dalam mempelajari materi program linier. Tujuan dari ini penelitian ini adalah untuk menemukan masalah-masalah yang dihadapi oleh dosen atau mahasiswa dalam proses perkuliahan program linier ditemukan solusi untuk menyelesaiakan masalah tersebut. Sehingga peneliti menggunakan software kvisoft yang dipadukan dengan geogebra untuk membuat media pembelajaran yang belum pernah dibuat sebelumnya.

Berdasarkan uraian diatas, peneliti bermaksud mengungkap analisis kebutuhan dalam pengembangan multimedia interaktif berbasis kvisoft flipbook maker dipadukan dengan software geogebra pada mata kuliah program linier. Lebih lanjut, Nation and Macalister (2010:24) menyatakan beberapa pertimbangan ketika melaksanakan analisis kebutuhan. Pertama, analisis kebutuhan langsung menyasar tujuan dan isi materi atapun subjek pembelajaran. Kedua, analisis kebutuhan dibutuhkan untuk mengungkap apa yang sudah diketahui oleh mahasiswa dan apa yang perlu diketahui oleh mahasiswa. Kemudian analisis kebutuhan dibutuhkan untuk menciptakan keyakinan bahawa mahasiswa atau materi mengandung hal hal yang relevan dan berguna bagi siswa.

\section{Metode Penelitian}

Penelitian ini menggunakan pendekatan deskriptif kualitatif yaitu menganalisis hasil wawancara terhadap mahasiswa yang menempuh mata kuliah Program Linier. Penelitian dilakukan di Prodi Pendidikan Matematika FKIP UAD. Subyek dari penelitian ini adalah mahasiswa yang menempuh mata kuliah Program Linier tahun ajaran 2017/2018. Prosedur dari penelitian ini adalah dengan melakukan wawancara secara mendalam kepada mahasiswa mengenai kebutuhan ketersediaan media pembelajaran mandiri yang dapat digunakan untuk meningkatkan hasil belajar mahasiswa 
terhadap mata kuliah program linier serta menggambarkan pandangan mahasiswa terhadap kebutuhan bahan ajar dalam program linier. Fokus penelitian ini adalah analisis masalah mahasiswa dalam program linier, analisis kebutuhan mahasiswa dalam pengembangan multimedia berbasis kvisoft yang dipadukan dengan geogebra. Teknik analisis data yang digunakan adalah analisis deskriptif terhadap hasil wawancara dan angket terhadap mahasiswa untuk mengungkap masalah dalam proses pembelajaran, kesulitan yang dihadapi serta bahan ajar yang digunakan mahasiswa.

\section{Hasil dan Pembahasan}

Berdasarkan hasil angket yang diberikan kepada mahasiswa yang menempuh mata kuliah Program Linier pada tahun ajaran 2017/2018, sebagian besar mahassiswa membutuhkan multimedia agar dapat memahami konsep materi dengan baik. Data angket terdapat pada tabel 1 .

Tabel 1. Data angket responden

\begin{tabular}{|c|c|c|}
\hline No. & Pertanyaan & Nilai \\
\hline 1. & $\begin{array}{l}\text { Mahasiswa mengalami kesulitan dalam } \\
\text { memahami materi metode grafik dan garis } \\
\text { selidik pada mata kuliah program linier tanpa } \\
\text { menggunakan media }\end{array}$ & $\begin{array}{l}86,67 \% \text { mahasiswa } \\
\text { mengalami kesulitan }\end{array}$ \\
\hline 2. & $\begin{array}{l}\text { Sumber belajar yang digunakan mahasiswa } \\
\text { hanya buku }\end{array}$ & $\begin{array}{l}100 \% \text { mahasiswa hanya } \\
\text { menggunakan buku }\end{array}$ \\
\hline 3. & $\begin{array}{l}\text { Mahasiswa mengalami kendala dalam } \\
\text { memahami sumber belajar yang berupa buku }\end{array}$ & $\begin{array}{l}80 \% \text { mahasiswa } \\
\text { mengalami kendala }\end{array}$ \\
\hline 4. & $\begin{array}{l}\text { Disediakannya sumber belajar berbasis } \\
\text { multimedia untuk materi metode grafik dan } \\
\text { garsi selidik }\end{array}$ & $93,3 \%$ mahasiswa setuju \\
\hline 5. & $\begin{array}{l}\text { Penggunaan multimedia pembelajaran untuk } \\
\text { perkuliahan program linier }\end{array}$ & $86,67 \%$ mahasiswa setuju \\
\hline 6. & $\begin{array}{l}\text { Isi dari sumber belajar yang berbasis } \\
\text { multimedia berupa materi, contoh soal } \\
\text {,simulasi, video }\end{array}$ & $86,67 \%$ mahasiswa setuju \\
\hline
\end{tabular}

Berdasarkan data diatas sebagian besar mahasiswa mengalami kesulitan dalam memahami materi pada perkuliahan program linier dikarenakan kurangnya 
media pembelajaran yang berbasis visual, sehingga kebutuhan akan dikembangkannya media berbasis multimedia kvisoft dipadukan dengan geogebra sangat perlu agar mahasiswa mendpatkan media pembelajaran sebagai sumber belajar mandiri, efektif efisien dan juga dapat memahamkan konsep materi pada mata kuliah program linier.

Berdasarkan hasil wawancara secara mendalam dengan beberapa mahasiswa menunjukkan bahwa ada beberapa kendala dalam proses pembelajaran pada mata kuliah Program Linier yaitu mahasiswa mengalami kesulitan ketika harus memahami materi mengkonkretkan daerah layak dari suatu grafik dikarenakan banyaknya fungsi kendala yang diberikan pada suatu masalah program linier yang berdampak pada kurang tepatnya penyelesaian program linier yang disajikan. Kesulitan ini dipicu karena kurang detailnya penjelasan yang diberikan oleh dosen pengampu karena keterbatasan media yang digunakan, yaitu hanya menggunakan papan tulis dan spidol yang terkadang dibantu penggaris seadanya. Media yang digunakan dosen untuk menjelaskan daerah layak tidak menggunakan visualisasi yang berwarna warni sehingga mahasiswa kesulitan untuk menentukan daerah arsiran dari masing-maisng kendala yang menyebabkan penentuan daerah layak dan titik optimum menjadi kurang tepat. Selain itu ketidaktepatan membuat grafik garis lurus untuk suatu kendala yang memuat bilangan-bilangan desimal berakibat tidak tepatnya titik optimum yang akan dicari. Hal ini berimbas pada materi selanjutnya yaitu kejadian kejadian khusus pada program linier yang menggunakan metode grafik. Dari suatu masalah Program Linier terdapat beberapa masalah Program Linier yang merupakan kejadian khusus seperti soal tidak layak, soal mempunyai alternatif penyelesaian, soal mempunyai daerah layak tidak terbatas, soal redundant, soal mempunyai penyelesaian tak terbatas. Jika penentuan daerah layak yang dilakukan mahasiswa tidak tepat maka kesimpulan dari masalah suatu Program Linier menjadi tidak tepat pula. Oleh karena itu mahasiswa berharap akan adanya media yang dapat menggambar secara visual dan berwarnawarni untuk penggambaran detail langkah-langkah pengarsiran daerah dari masing-masing kendala sehingga muncullah daerah layak dan titik optimum yang dapat menyelesaikan soal program linier yang diberikan. untuk memahami konsep penyelesaian Program Linier dengan menggunakan metode garis selidik. Sebelum memasuki materi garis selidik mahasiswa sudah kebingunan mengenai penentuan daerah layak dari 
suatu program linier dan pada materi garis selidik masih ditambah lagi konsep pergerakan garis dari fungsi tujuan (garis selidik) yang menentukan penyelesaian dari suatu program linier. Kebingunan mahasiswa dimulai dari cara menggerakkan garis selidik tersebut dan dari pergerakan tersebut dapat ditentukan nilai optimum dari suatu masalah program linier. Mahasiswa tidak paham bagaimana cara menggeser garis selidik tersebut dikarenakan simulasi yang diberikan oleh dosen hanya berupa menggeser penggaris, padahal pergeseran penggaris tersebut haruslah sejajar. Jika pergeseran tersebut tidak sejajar dengan garis selidik awal maka penyelesaian dari masalah program linier menjadi kurang tepat. Hal ini menyebabkan dosen harus mendatangi mahasiswa satu-persatu untuk menjelaskan cara pergeseran garis selidik tersebut untuk menentukan penyelesaian optimum dari masalah program linier. Kegiatan ini sangat menyita waktu dan tenaga juga keefektifan perkuliahan, sehingga diperlukan media yang dapat mensimulasikan konsep dari garis selidik yang dapat membantu mahasiswa memahami konsep garis selidik tanpa harus bertanya terus menerus kepada dosen. Mahasiswa berharap disediakannya media pembelajaran yang dilengkapi dengan gambar grafik yang mempunyai warna yang berbeda dan melakukan simulasi.

Sumber belajar yang digunakan mahasiswa selama perkuliahan masih berupa buku dengan gambar grafik yang tidak berwarna dan tidak disertai adanya simulasi penyelesaian sistem persamaan linier dengan menggunakan grafik dan garis selidik. Karena sumber belajar yang digunakan mahasiswa hanya berupa buku maka penerimaan konsep mahasiswa masih lemah dan mudah lupa terhadap materi yang sudah dijelaskan oleh dosen didalam perkuliahan. Dengan media pembelajaran yang berbasis kvisoft maka akan membantu mahasiswa dalam memahami konsep dari program linier serta sebagai sumber belajar mandiri bagi mahasiswa. Selain itu dengan menggunakan geogebra, mahasiswa dapat melihat simulasi penyelesaian dengan menggunakan metode grafik dan metode garis selidik. Ini sejalan dengan pendapat Sakat (2012) yang menyatakan bahwa pembelajaran yang menggunakan teknologi media akan memberikan pengaruh yang signifikan dalam pembelajaran.

\section{Kesimpulan}

Berdasarkan hasil penelitian yang telah dilakukan dapat disimpulkan bahwa dalam perkuliahan Program Linier 
mahasiswa membutuhkan media pembelajaran yang interaktif, mandiri, efektif dan efisien yang dapat membantu meningkatkan pemahaman materi kuliah. Penelitian ini merupakan penelitian awal dari bagian penelitian pengembangan media pembelajaran berbasis kvisoft yang dipadukan dengan geogebra pada mata kuliah program linier, Sehingga masih dibutuhkan penelitian lebih lanjut untuk mengukur validitas dari media pembelajaran yang dikembangkan.

\section{Ucapan Terimakasih}

Penelitian ini dibiayai oleh Hibah Penelitian Dosen Pemula (PDP) dari DRPM KEMENRISTEKDIKTI Tahun Anggaran 2018 Nomor : PDP058/SKPP/III/2018.

\section{Pustaka}

Fahmi, S. 2014. Pengembangan multimedia macromedia flash dengan pendekatan kontekstual dan keefektifannya terhadap sikap siswa pada matematika. Jurnal AgriSains, 5(2).

Frangenheim, E, 2005, Reflection on Classroom Thinking Strategies: Practical Strategies to Encourage Thinking in Your Classroom, London: Paul Chapman Publisihing
Gunawan, Dedi, 2010, Modul Pembelajaran Interaktif

Elektronik Dasar untuk Program Keahlian Teknik Audio Video SMK Muhammadiyah

Sukoharjo Menggunakan Macromedia Flash 8, Jurnal Komuniti Vol.2 No.1:Teknik Elektro Universitas

Muhammadiyah Surakarta

Majid, A, 2008, Perencanaan Pembelajaran Mengembangkan Standar Kompetensi Guru, Bandung: $\quad$ PT.Remaja Rosdakarya.

Nation, I. S.P. \& John Macalister, 2010,Language Curriculum Design, NewYork \& London : Routledge

Nazeri, 2013, Penggunaan E-Flipbook dalam topik Elektrik dan Elektronik: Inovasi dalam Penggunaan Bentuk dan Teknologi PISMP RBT, Prosiding Seminar Penyelidikan IPG Zon Timur

Prastowo, A, 2012, Panduan Kreatif Membuat bahan Ajar Inovatif, Yogyakarta:Diva Press

Prastowo, A, 2013, Pengembangan Bahan Ajar Tematika, Yogyakarta:Diva Press

Ramdania, Diena Randa, 2013, Penggunaan Media Flash 
Flipbook dalam Pembelajaran

Teknologi Informasi dan

Komunikasi untuk

Meningkatkan Hasil Belajar

Siswa, Bandung :UPI

Sakat, A.A, Mohd. Zin, M.Z., Mohammed, R., Ahmad, A. Ahmad, H.A, and Karno, M.A, 2012. Educational Media Technology in Teaching and Learning Method in Progress, American Journal of Applied Sciences, 874-888. 
